\title{
The effect of two compost soil amendments, based on municipal green and penicillin production wastes, on plant parasitic nematodes
}

\author{
M. RENČO ${ }^{1}$, N. SASANELLI ${ }^{2}$, P. ŠALAMÚN ${ }^{1}$ \\ ${ }^{1}$ Parasitological Institute, Department of Plant Nematology, Slovak Academy of Sciences, Hlinkova 3, 04001 Košice, \\ Slovak Republic, E-mail: renco@saske.sk; ${ }^{2}$ Institute for Plant Protection, Section of Nematology, National Council \\ of Researches, Via G. Amendola 122/D, 70126 Bari, Italy, E-mail: n.sasanelli@ba.ipp.cnr.it
}

\begin{abstract}
Summary
Suppressive effect of two composts, applied at five doses $(0 \%, 1 \%, 2.5 \%, 5 \%$ and $10 \% \mathrm{w} / \mathrm{w})$, was studied on spring barley to control different genera of plant parasitic nematodes in potting mixtures. Amendment of soil with these materials resulted in a significant decreasing effect of plant parasitic nematode populations. The best reduction of number of plant parasitic nematodes was found for the nematode genera Bitylenchus, Helicotylenchus, Heterodera, Paratylenchus and Rotylenchulus by a municipal green compost $\left(\mathrm{C}_{1}\right)$ and nematode genera Bitylenchus, Geocenamus, Helicotylenchus, and Rotylenchulus by a compost derived from penicillin production residues $\left(\mathrm{C}_{2}\right)$. The compost $\mathrm{C}_{1}$ with a lower $\mathrm{C}: \mathrm{N}$ ratio was more effective in the nematode control than the compost $\mathrm{C}_{2}$. The analysis of variance showed a significant interaction among all factors involved in the experiment: type of compost, different doses and nematode genera. Relationship between applied doses and number of nematodes showed a significantly high negative correlation.
\end{abstract}

Keywords: plant parasitic nematode; compost; suppression; compost amendment

\section{Introduction}

Phytoparasitic nematodes are a serious threat to numerous crop plants of agricultural interest (Lišková \& Renčo, 2007; Kumari \& Decreamer, 2007, Renčo \& Čerevková 2008), can cause their yield losses (Seinhorst, 1986; Sasanelli, 1994). Control of these phytoparasitic nematodes, as for soil pathogens and weeds, has been generally based on chemical treatments (Basile et al., 2003).

In every case the increasing attention to the environment safety and to the human health, require to find new alternative control strategies, environmentally sound and economically convenient at the same time (Bridge, 1996; Ciccarese et al., 2008; Sasanelli et al., 2008).
Among these alternative strategies use of organic amendments may be interesting because of their low cost and the more general positive agronomical effects related to the incorporation of organic matter into the soil (Sasanelli et al., 2002). Use of organic amendments is known to suppress soil phytoparasitic nematode populations since many years (Linford et al., 1938), although research was improved in the past decade by the above reported environmental concerns (D’Addabbo, 1995).

Organic matter is known to affect physical, chemical and biological properties of the soil (Davey, 1996). Incorporating organic amendments have a direct impact on plant health and crop productivity (Rodríguez-Kábana, 1986; Akthar \& Malik, 2000). There are more than sufficient data to indicate that organic materials reduce disease incidence caused by a wide range of plant pathogens and plant pests including bacteria, fungi and nematode species (Abawi \& Widmer, 2000; Bailey \& Lazarovits, 2003). Disease suppressive conditions have been obtained in soil following addition of composts from different origin (Hadar et al., 1992; Hoitink \& Fahy, 1986).

D'Addabbo (1995) has reviewed the literature on organic amendments dating from 1982 to 1994 and found 224 papers concerning the use of different animal and plant wastes as nematode suppressant.

Incorporation into the soil of olive and grape pomace soil amendments significantly reduced the density population of the root-knot nematode Meloidogyne incognita in the soil (D'Addabbo \& Sasanelli, 1998; Sasanelli \& D'Addabbo, 2002).

Other organic soil amendments significantly reduced the populations of root-knot nematodes, Meloidogyne spp. (Oka \& Yermiyahu, 2002; Pérez et al., 2003). Similarly, Ismail et al., (2006) and Renčo et al. (2007) observed the suppression of nematode populations of Rotylenchulus reniformis and Globodera rostochiensis in compost amended soils. Soil treated by vermicomposts contains 
a lower number of plant parasitic nematodes than nonamended soil (Ribeiro et al., 1998; Arancon et al., 2003).

The plant parasitic nematodes were also suppressed by application of poultry manure (Khan et al., 2001b; Conn \& Lazarovitz, 1999), pigeon manure (Khan et al., 2001b), chicken manure (Gonzalez \& Canto-Sanenz, 1993; D'Addabbo et al., 2003), sawdust (Khan et al., 2001b) as well as by many others organic matters.

Mechanisms of this suppressive action seem to be related to the release of nemato-toxic compounds and/or ammoniacal nitrogen liberation during the degradation of organic matter and to the increased activity of naturally occurring antagonists (predators and parasites) of nematode pests (Stirling, 1991).

However, in other cases, no inhibition or increase in populations of plant parasitic nematodes in soil amended with organic materials was observed (Kimpinski et al., 2003; McSorley \& Gallaher, 1995, 1996). On the other hand, Akhtar \& Mahmood (1994) reported an increase in numbers of predatory and free-living nematodes after soil amendments with composted manures and urea. There are several other studies which confirm that soil organic amendments improved the beneficial free living nematode (Griffits et al., 1994; Arancon et al., 2003; Nahar et al., 2006).

Therefore, an experiment was carried out in outdoor condition, considering that: i) the use of composts is a nematode control strategy at low enviromental impact, ii) the composting process must be considered as a part of an integrated waste solution and iii) the large amount of the organic materials produced every year are at low cost. In particular, the aim of this study was to test the ability of two different composts produced in Slovak Republic, from municipal wastes and agroindustrial byproducts, with a different $\mathrm{C} / \mathrm{N}$ ratio, to suppress various genera of plant parasitic nematodes in natural infested soils and to investigate the relationship between the dynamic of nematode population density and the applied compost rates.

\section{Material and methods}

Two different composts, $\mathrm{C}_{1}$ and $\mathrm{C}_{2}$, suitable for soil application were used in the experiment. The $\mathrm{C}_{1}$ compost (municipal green compost) consisted of grass $(60 \%)$, leaves $(25 \%)$, tree branches $(5 \%)$ and soil $(10 \%)$ with a $\mathrm{pH}$ of 7.7 and the $\mathrm{C} / \mathrm{N}$ ratio of $4.2: 1$. The $\mathrm{C}_{2}$ compost (commercially produced) was a by-product of penicillin production, mycelium (90\%), straw (5\%) and sawdust (5\%) with a pH of 7.7 and the $\mathrm{C} / \mathrm{N}$ ratio of $20: 1$.

Composts were added and thoroughly mixed with nematode naturally infested soil at 1.0, 2.5, 5.0, $10.0 \% \mathrm{w} / \mathrm{w}$ rates of dry weight. The sandy-loam soil used was collected from a cultivated field situated near the city of Košice. Each mixture $(400 \mathrm{~g})$ was then poured into a 350 $\mathrm{ml}$ plastic pot, with eight replicates per treatment. Nonamended soil was used as a control. Spring barley seeds were then sown into each pot. Pot experiment was arranged under outdoor conditions according to a randomized block design and focused only to study the effect of compost applications on plant parasitic nematode population in the amended soil and to investigate the relationship between applied compost rates and the dynamic of nematode population density. Differences in growth of barley plants in the different treatments were not studied.

At the end of the experiment, after four months, the soil was taken from each pot and nematodes were isolated by the Cobb flotation-sieving method (1918), fixed in FAA and identified microscopically to genera level.

Data from the experiment were statistically analysed by the factorial analysis of variance (ANOVA) for a $2 \times 5 \times 7$ factorial design, and means compared by the Least Significant Difference's Test and Student's $t$ test.

Suppression of nematode genera by treatments was investigated through regression analyses conducted by program for simple equations models (linear, power, exponential and logarithmic) of Table-Curve Windows v1.0 (Jandel Scientific).

\section{Results}

Seven genera of plant-parasitic nematodes were identified in the control and treated pots (Table 1). In general comparison, the compost $\mathrm{C}_{1}$ significantly reduced the number of Helicotylenchus, Heterodera, Paratylenchus and Rotylenchulus nematodes in comparison to compost $\mathrm{C}_{2}$ (Table 1). No statistical difference was observed between the two composts for Bitylenchus, Geocenamus and Pratylenchus genera.

All tested rates $(1,2.5,5$ and $10 \% \mathrm{w} / \mathrm{w})$ of municipal green compost $\mathrm{C}_{1}$ significantly reduced the number of Bitylenchus, Helicotylenchus, Heterodera, Paratylenchus and Rotylenchulus compared with no amended soil (control) $(\mathrm{P}=0.01)$ (Table 2). However, a reduction of population of Geocenamus and Pratylenchus genera was only

Table 1 General comparison of the effect of the tested composts on different genera of plant parasitic nematodes

\begin{tabular}{cccc}
\hline \multirow{2}{*}{ Nematode genera } & \multicolumn{2}{c}{ Nematodes number } & \multirow{2}{*}{ Student's $\boldsymbol{t}$ test } \\
\cline { 2 - 4 } & $\mathbf{C}_{\mathbf{1}}$ & $\mathbf{C}_{\mathbf{2}}$ & --- \\
Bitylenchus & 5.1 & 6.5 & -- \\
Geocenamus & 14.8 & 10.8 & $*$ \\
Helicotylenchus & 10.4 & 16.9 & $*$ \\
Heterodera & 0.8 & 1.5 & $*$ \\
Paratylenchus & 10.7 & 15.2 & -- \\
Pratylenchus & 3.3 & 3.6 & $* *$ \\
Rotylenchulus & 30.5 & 51.5 & \\
\hline
\end{tabular}

* Significant for $\mathrm{P}=0.05 ; * *$ for $\mathrm{P}=0.01$ 


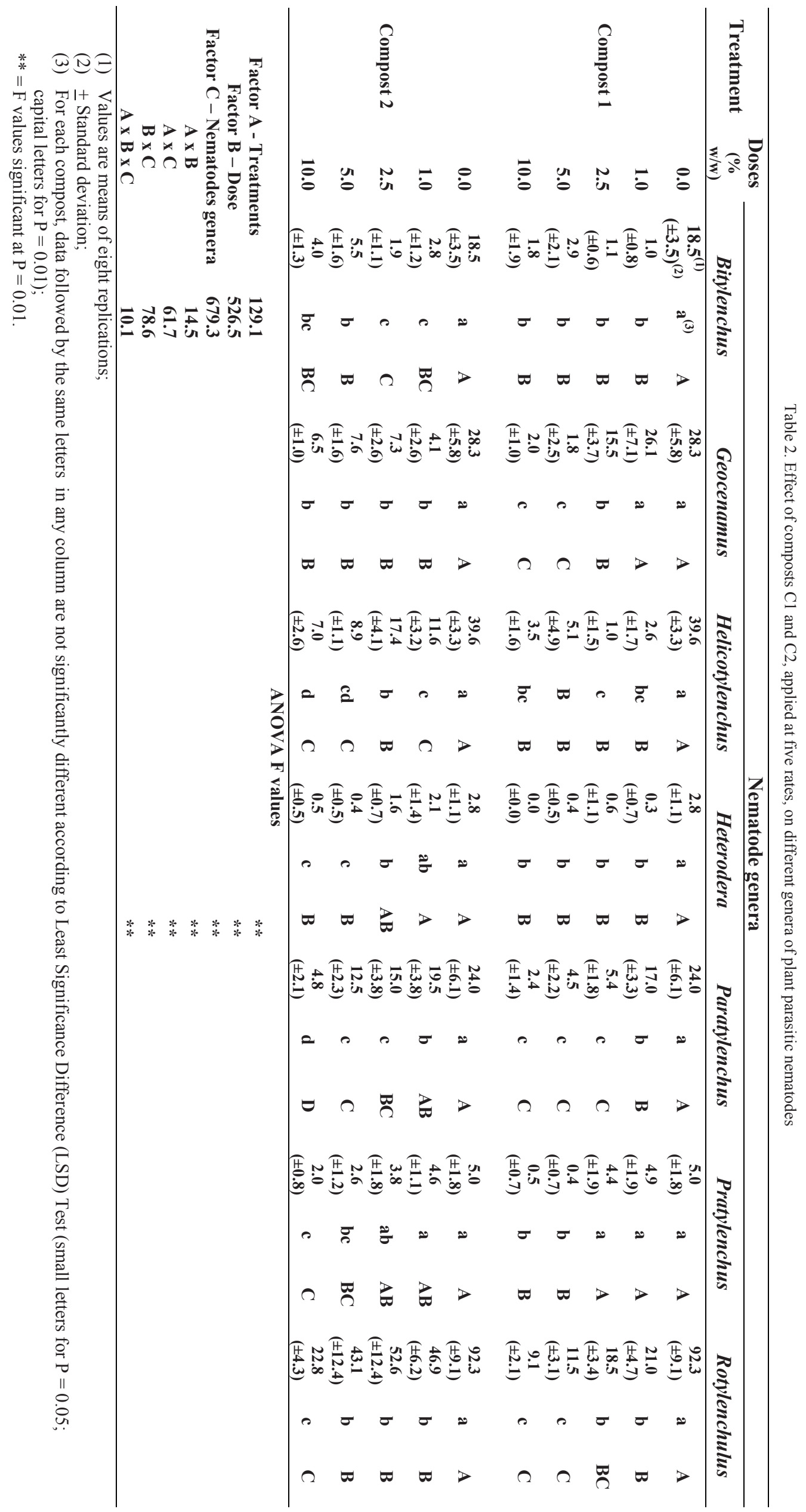



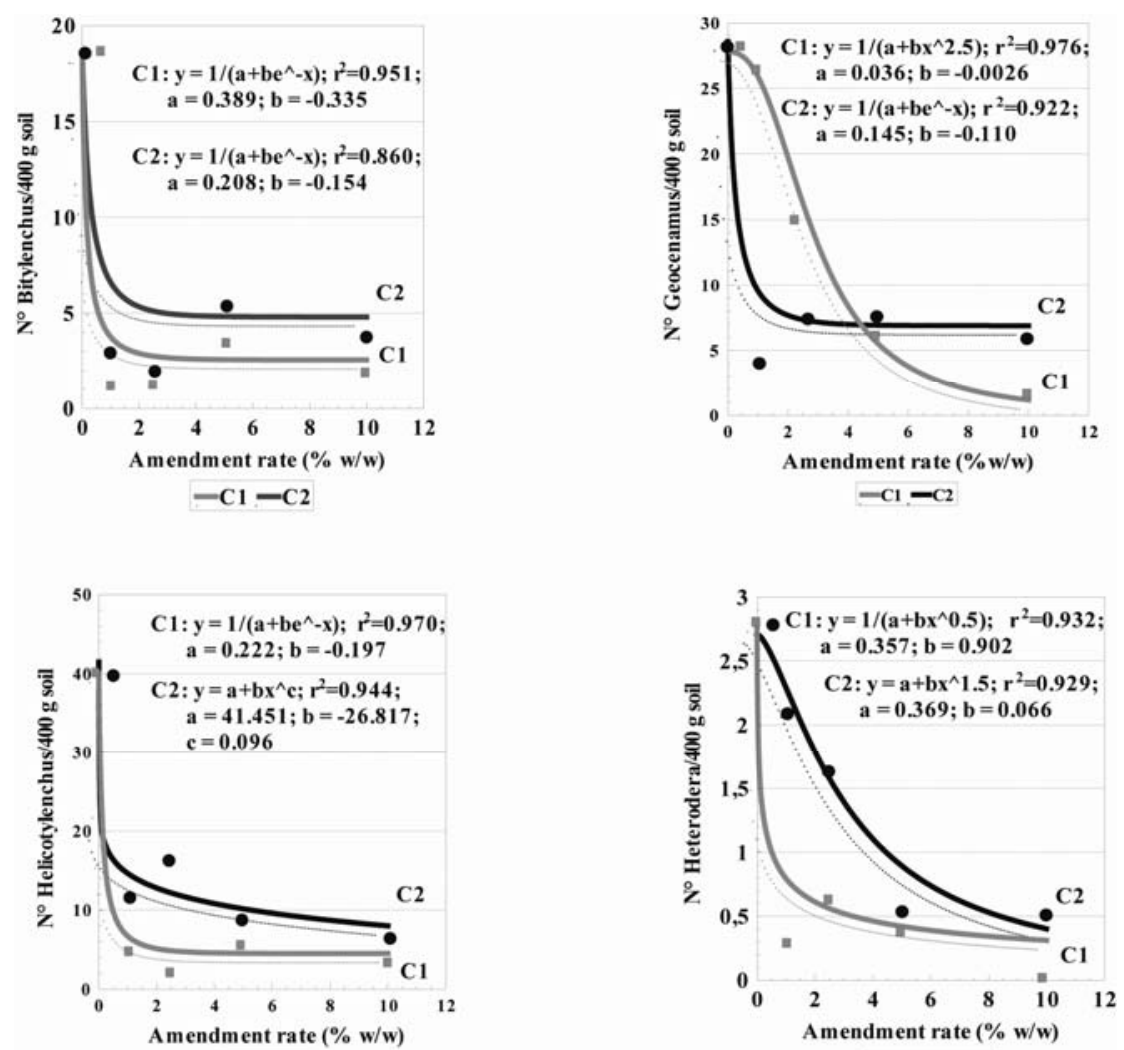

$-\mathrm{Cl}_{1}-\mathrm{C}_{2}$
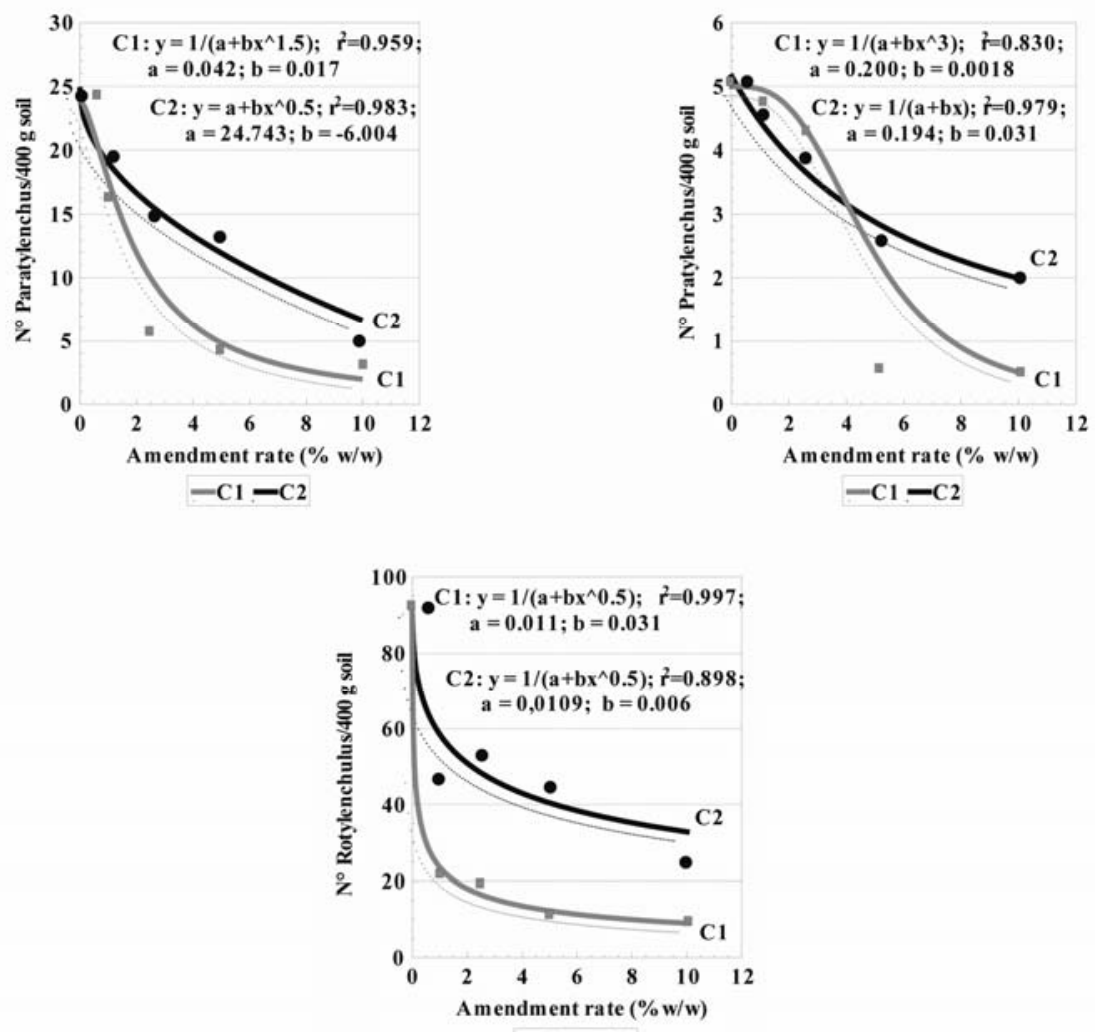

Fig. 1. Relationship between rates of composts $\mathrm{C} 1$ and $\mathrm{C} 2$ amending the pot mixtures $(0 \%, 1 \%, 2.5 \%, 5 \%, 10 \%)$ and number of nematodes in each genera. Each point represents the average of eight replications. Lines represent the predicted function calculated by fitting experimental data to different equations. 
observed at $2.5 \%$ and $5 \% \mathrm{C}_{1}$ rates, respectively (Table 2 ). In compost $\mathrm{C}_{1}$, all tested doses were not statistically different each other to reduce Bitylenchus, Helicotylenchus and Heterodera populations $(\mathrm{P}=0.01)$. In every case, no statistical differences were observed between the two highest rates for all nematode genera $(\mathrm{P}=0.01)$ (Table 2$)$.

In the potting mixtures, with compost $\mathrm{C}_{2}$ a similar significant reduction of plant parasitic nematodes in the soil was observed at all tested rates compared with untreated control, except the genus Heterodera, Paratylenchus and Pratylenchus $(\mathrm{P}=0.01)$ (Table 2$)$. To obtain a significant reduction $(\mathrm{P}=0.01)$ of number of Heterodera and Pratylenchus it was necessary a minimum of $5 \%(\mathrm{w} / \mathrm{w})$ rate, whereas a $2.5 \%$ dose of compost $\mathrm{C}_{2}$ was useful to reduce Paratylenchus populations. No significant difference was found between the two highest rates in Bitylenchus, Geocenamus, Helicotylenchus, Heterodera and Pratylenchus genera (Table 2).

To study the interactions among the different factors involved in the experiment the analysis of variance was performed on three factors: i) factor A, the type of compost (two levels), ii) factor B, the applied rates (5 levels) and iii) factor $\mathrm{C}$, the nematode genera (seven levels). The analysis of variance showed for factor $\mathrm{A}$ a high significant interaction with the factors $\mathrm{B}$ and $\mathrm{C}$ at $\mathrm{P}=0.01$ ( $\mathrm{A} \times \mathrm{B}$ and $\mathrm{A} \times$ C). Also the interaction between the factor $\mathrm{B}$ and factor $\mathrm{C}$ (B x C) was highly significant $(\mathrm{P}=0.01)$. So all factors involeved in the experiment were significanly correlated each other (A x B x C) as reported in Table 2 .

The relationship between amendment rates and number of nematodes showed a high significant negative correlation in each nematode genus (Fig. 1). In each fitting curve the values observed in $\mathrm{C}_{1}$ compost were lower than that observed with compost $\mathrm{C}_{2}$. Only in Geocenamus and Pratylenchus genera, the values recorded in $\mathrm{C}_{2}$ were higher than that of $\mathrm{C}_{1}$ for $1 \%$ and $2.5 \%$ rates (Fig. 1 ).

\section{Discussion}

Results of our experiment demonstrated that soil treatments with municipal green compost and compost derived from the penicillin production residues significantly suppressed the number of plant parasitic nematodes compared to non-amended soil.

Numerous research studies worldwide also showed that organic amendments of soil are a means of the nematode control (Arancon et al., 2003; Nahar et al., 2006; Renčo et al., 2007). However, in plant parasitic nematodes, efficiency of suppression in organic amendment varies depending upon nematode species and type of organic matter (Akthar \& Alam, 1993). This influence is often variable and conflicting. Gallaher and McSorley (1996) reported that the number of plant parasitic nematodes Criconemella spp. and Pratylenchus spp. was lower in plots amended with yard waste compost compared to untreated plots. Suppression of Pratylenchus penetrans population was observed on potato by applying poultry manure (Conn \& Lazarovits, 1999) or, in microplot condition, adding to the soil mushroom composts (LaMondia et al., 1999). However, no reduction in populations of Pratylenchus and Meloidogyne nematodes, after compost amendment, was observed by McSorley and Gallaher (1995), Kimpinski et al., (2003) and Yao et al. (2006). In our test, the two lower doses of municipal green compost and compost from penicillin residues significantly no reduced the number of Pratylenchus nematodes compared to untreated control, whereas the two highest doses were effective in the control (Table 2).

The level of reduction of plant parasitic nematodes increased with higher doses and over longer periods of treatments (Gutpa \& Kumar, 1997). Similar findings were reported by Akhtar (1999), in which increasing applied doses of compost treatments caused a progressive reduction of the number of plant parasitic nematodes. In our experiment, a significant reduction of nematode number associated with an increasing dose of compost addition was observed in nematodes of the genera Bitylenchus, Helicotylenchus, Paratylenchus and Rotylenchulus in $\mathrm{C}_{1}$ and $\mathrm{C}_{2}$ compost, Heterodera in $\mathrm{C}_{1}$ and Geocenamus in $\mathrm{C}_{2}$ compost. Khan et al., $(2001 \mathrm{a}, \mathrm{b})$ reported the reduction of population densisties of Tylenchorhynchus curvus, Helicotylenchus indicus and Merlinius brevidens by organic amendments of pigeon manure, poultry, horse and donkey manure and saw dust, at all applied doses. A reduction of number of Heterodera, Paratylenchus and Tylenchorhynchus nematodes by compost application was also obtained by Yao et al., (2006). As reported by Kimpinski et al., (2003), the addition of compost amendments in barley plots increased Heterodera trifolli populations, although, this species parasitized the preceding red clover crop, but not barley. They stated that compost treatments may have stimulated egg hatching. A similar, vermicompost application had no effect on Heterodera schachtii population (Szczech et al., 1993). On the contrary, soil from the vermicompost treated plots contained lower populations of plant parasitic nematodes than soil from inorganic fertilizer treated plots (Arancon et al., 2003).

In our study, Rotylenchulus along with other nematode genera were significantly suppressed by the addition of composts to soil, as also found by Ismail et al. (2006). They found a positive correlation between applied doses of seven compost treatments and reduction of population of Rotylenchulus reniformis.

In general, the efficacy of nematode suppression by organic amendments depends on the $\mathrm{C}: \mathrm{N}$ ratio and a time of microbial decomposition of organic matter (RodriguezKabana et al., 1995; D’Addabbo \& Sasanelli, 1997; Akhtar \& Malik, 2000). Kirmani et al., (1975) changed the C:N ratio in organic treatments and observed that when more nitrogen sources was available, nematode control was enhanced. This also confirms our results because $\mathrm{C}_{1}$ compost with the lower $\mathrm{C}: \mathrm{N}$ ratio $(4.2: 1)$ had the best effect on reduction of number of plant parasitic nematodes in comparison to compost $\mathrm{C}_{2}$ (Fig. 1). Similarly, Ismail et al., (2006) found the best reduction in the number of Rotylenchulus reniformis after applying the composts with lower 
$\mathrm{C}: \mathrm{N}$ ratio $(\mathrm{C}: \mathrm{N}=6.7: 1)$. The application of slurry $(\mathrm{C}: \mathrm{N}=8: 1)$ and fruit or garden waste compost (C:N=10:1) reduced the population of Pratylenchus spp. and Tylenchidae in maize monoculture (Leroy et al., 2007). Reversal, yard waste compost (leaves, branches, grass clippings) with the C:N ratio from 35:1 to 46:1 had no effect on population densities of Pratylenchus spp. and Meloidogyne incognita (McSorley \& Gallaher, 1996).

On the other hand, the organic amendments supported the beneficial free-living nematodes, mainly bacterial feeding nematodes (Griffits et al., 1994; Nahar et al., 2006). Arancon et al. (2003) found that vermicomposts applications increase population of bacterial and fungal feeding nematodes in field crops. Edwards (1988) stated that vermicomposts improved the microbial activity by providing resources for the growth of soil bacteria and some fungi. Griffiths et al. (1994) also reported that number of bacterial and fungal feeding nematodes in organic management systems tend to increase their numbers, as the organic matter provides a food base for them.

In our experiment, significant nematode suppression was found at all tested concentration of compost including the low doses of $1 \%$ and $2.5 \%$, with the exception of Pratylenchus for both composts, which is important in field applications. The higher application doses would be more difficult to achieve on a practical basis. Although both the tested composts significantly reduced the number of plant parasitic nematodes in comparison to untreated control, our results confirm that the compost with the low C:N (4.2:1) ratio is more effective in suppression of plant parasitic nematodes than the compost by-product of penicillin production with a C:N ratio of 20:1. The composts release compounds toxic to plant nematodes like phenols, tannins, terpens, (Mian \& Rodriguez-Kabana, 1982) or derived from decomposition processes in the soil, like ammonia, nityrites, hydrogen sulphide (Rodriguez- Kabana, 1986). So, the higher nitrogen content in $\mathrm{C}_{1}$ might explain the more effective nematicidal activity observed in this compost in comparison to $\mathrm{C}_{2}$ (Fig. 1). Moreover, considering the relatively low dosages needed and the large availability at low or zero cost of municipal green and penicillin production wastes make the use of these organic residues easy, immediate and promising in economical convenient composting processes. The main aim of compost use should be a progressive reduction of infestation level under thew tolerance limit of the target nematode species (Sasanelli, 1994; McSorley \& Duncan, 1995).

Therefore, our results confirm the potential of using different locally available composted agro-industrial or municipal wastes as an alternative plant parasitic nematode control method, at low environmental impact, to chemicals.

\section{Acknowledgement}

The authors acknowledge the support of the scientific grant agency VEGA (Grant No. 2/7191/27). The research was undertaken within the framework of a bilateral project between the Slovak Academy of Science and the Italian
National Council of Research (2006-2009).

\section{References}

ABAWI, G. S., WIDMER, T. L. (2000): Impact of soil health management practices on soilborne pathogens, nematodes and root diseases of vegetable crops. Appl. Soil. Ecol. 15: $37-47$

AKTHAR, M. (1999): Plant growth and nematode dynamics in response to soil amendments with neem products, urea and compost. Biores. Technol. 69, $181-183$

AKTHAR, M., Alam, M. M. (1993): Utilization of waste materials in nematode control. A review . Biores. Technol. $45,1-7$

AKTHAR, M., MAHMOOD, I. (1994): Potentiality of phytochemicals in nematode control: a review: Biores. Technol. 47, $189-201$

AKTHAR, M., MaliK, A. (2000): Roles of organic amendments and soil organisms in the biological control of plant parasitic nematodes: a review. Biores. Technol. 74, $35-$ 47

Arancon, N. Q., Galvis, P., Edwars, C., Yardim, E. (2003): The trophic diversity of nematode communities in soil treated with vermicompost. Pedobiologia 47, 736 740

BAILey, L. L., LaZARovits, G. (2003): Suppressing soilborne diseases with residue management and organic amendments. Soil \& Tillage Research, 72: $169-180$

Basile, M., D'addabbo, T., Sasanelli, N., Basile, A. C. (2003): Fumiganti e nematocidi sistemici in vivaio. (English: Fumigants and systemic nematicides in nurseries). Italus Hortus, 10 (S4): 294 - 296

BRIDGE, J. (1996): Nematode management in sustainable and subsistence agriculture. Annual Review of Phytopatholog, v. 34: $201-225$

Ciccrese, F., Sasanelli, N., Gallo, M., Papajova, I., RENCO, M. (2008): Biological control of Fusarium-wilt and the root-knot nematode Meloidogyne incognita on Cucumis melo subsp. Melo conv. Adzhur (Pang.) Grebensch. In Proceedings Biotechnology 2008, $13-14$ February, Czech Budejovice, Czech Republic, pp. 33 - 35

СовB, N. A. (1918): Filter bed nemas: Nematodes of the slow sand filter beds of American cities. (Including new genera and species). With notes on Hermaphroditism and pathenogenesis. Contrib. Sci. Nematol. (Cobb), 7, $189-$ 212

CONN, K.L., LAZAROVITS, G., (1999): Impact of animal manures on Verticillium wilt, potato scab, and soil microbial population. Can. J. Plant Pathol. 21, 81 - 92

D'ADDABBO, T. (1995): The nematicidal effect of organic amendments: a review of the literature, 1982 - 1994. Nematol. mediterr., 23, $299-305$

D'ADDABbo, T., SASANElli,, N. (1997): Suppression of Meloidogyne incognita by combination of olive pomace or wheat straw with urea. Nematol. mediterr., 25: $159-164$ D'ADDABBO, T., SASANELLI,, N. (1998): The suppression of Meloidogyne incognita on tomato by grape pomace soil amendments. Nematologia mediterranea, 26: 145-149 
D’addabbo, T., Sasanelli,, N., Lamberti, F., Greco, P., CARElla, A. (2003): Olive pomace and chicken manure amendments for control of Meloidogyne incognita over two crop cycles. Nematropica 33: $1-7$

DAVEY, C. B. (1996): Nursery soil management - organic amendments. In: LANDis, T. D., DouTh D. B. (Tech. Coordinators), National Proceedings, Forest and Conservation Nursery Associations. General Technical Report PNWGTR-389: USDA Forest Service PNWRS, pp. 6-18

EDWARDS, C. A. (1998): Breakdown of animals, vegetable and industrial organic wastes by earthworms. In: Edwards, C. A. (Ed) Earthworm Ecology. CRC Press, Boca Raton, Florida, pp. 237 - 354

GAllaher, R. N., Mcsroley, R. (1996): Soil properties, nematode densities, and corn yield from yard waste compost applications. pp. 37 - 41. In: EAsH, N. (Ed) Proceedings Southern Conservation Tillage Conference for Sustainable Agriculture. Special Publication 96-07. University of Tennessee, West Tennessee Experiment Station, Jackson, TN

Gonzalez, A., CAnto-SAnenz, M. (1993): Comparison of live organic amendments for the control of Globodera pallida in microplots in Peru. Nematropica 23, 133 - 139

Griffiths, B. S., Ritz, K., WheAtLEY, R. E. (1994): Nematodes as indicators of enchanced microbiological acitivity in a Scotish organic farming system. Soil Use Manage. $10,20-24$

GUTPA, M., KUMAR, S. (1997): Efficacy of certain organic amendments and nematicides against Tylenchorhynchus spp. and Helicotylenchus spp. in soil. Indian J. Nematol. $27,139-142$

Hadar, Y., Mandelbaum, R., Goredecki, B. (1992): Biological control of soilborne plant pathogens by suppressive compost. In: TJAMOS, E. S., PAPAVIZAS, G. C., COOK, R. J. (Eds) Biological Control of Plant Diseases. Plenum Press, New York, pp. $79-83$

HoitinK, H. A. J., FAHY, P. C. (1986): Basis for the control of soilborne plant pathogens with composts. Annual Review of Phytopathology, 24: 93 - 114

ISMAIL, A. E., RAWIA, A. E, EL-NAGDI, W. M. A. (2006): Effect of different composts, biofertilizers and olive pomace as soil amendments on Rotylenchulus reniformis, growth and chemical analysis of jasmine Egypt. J. Appl. Sci. Res. 2, $909-916$

Khan, A., Shaukat, S. S. Ahmad, I. (2001a): Effects of Organic Manures and Carbofuran on Nematodes Associated with Garlic (Allium sativum L.). Pak. J. Biol. Sci. 4, $319-320$

Khan, A., Shaukat, S., QAmar, F., Islam, S., Hakro, A. A., JAFFrY, A. F. (2001b): Management of Plant Parasitic Nematodes Associated with Chilli Through Organic Soil Amendments. Pak. J. Biol. Sci. 4, $417-418$

Kimpinski, J., Gallant, C. E., Henry, R., Macleod, J. A., Sanderson, J. B., Sturz, A. V. (2003): Effect of compost and manure soil amendments on nematode and on yields of potato and barley: a 7-years study. J. Nematol. $35,289-293$

Kirmani, M. R., Alam, M. M., Khan, A. M., SaXena, S.
K. (1975): Effect of different carbon: nitrogen ratios on the population of nematodes and fungi and plant growth of cabbage. Indian J. Mycol. Plant Pathol. 5, 22

Kumari, S., DeCrEAMER, W. (2007): The genus Longidorus (Nematoda: Longidoridae) from Bohemia and South Moravia in the rhizosphere of fruit orchards and vineyards. Helminthologia, 44, 193 - 203

Lamondia, J. A., Gent, M. P. N., Ferrandino, F. J., Elmer, W. H., Stoner, K. A. (1999): Effect of compost amendment or straw mulch on potato early dying disease. Plant Dis. 83, 361 - 366

Leroy, B. L. M. M., Bommele, L., Reheul, D., Moens, M., DE NEVE, S. (2007): The application of vegetable, fruit and garden waste (VFG) compost in addition to cattle slurry in a silage maize monoculture: Effect on soil fauna and yield. Eur. J. Soil Biol. 43, $91-100$

Linford, M. B., YAP, F. Oliveira, J. M. (1938): Reduction of soil populations of root-knot nematodes during decomposition of organic matter. Soil Science, 45: $127-$ 141

LiŠKOVÁ, M., RENČO, M. (2007): Communities of free living and plant parasitic nematodes in hop gardens in Slovakia, Helminthologia, 44, $80-86$

Mcsorley, R., Duncan, L. W. (1995): Economic thresholds and nematode management. Adv. Plant Pathol. 11, 147 - 171

MCSORLEY, R., GALlAHER, R. N. (1995): Effect of yard waste compost on plant-parasitic nematode densities in vegetable crops. J. Nematol. 27, 545 - 549

MCSORley, R., GAllaher, R. N. (1996): Effect of yard waste compost on nematode densities and maize yield. $J$. Nematol. 28, 655 - 660

Mian, I. H., Rodriguez-Kabana, R. (1982): Organic amendments with high tannin and phenolic contents for control of Meloidogye arenaria in infested soil. Nematropica, 12: $221-234$

Nahar, M. S., Grewal, P. S., Miller, S. A., Stinner, D., Stinner, B. R., Kleinhenz, M. D., Wszelaki, A., DoOHAN, D. (2006): Differential effects of raw and composted manure on nematode community, and its indicative value for soil microbial, physical and chemical properties. Appl. Soil Ecol. 34, 140 - 151

OKA, Y., YERMIYAHU, U. (2002): Suppressive effects of composts against the root-knot nematode Meloidogyne javanica on tomato. Nematology 4, $891-898$

PÉrez, M., NAVAz-Cortés, J. A., PAscual-Villalobos, M., CAstillo, P. (2003): Nematicidal activity of essential oils and organic amendments from Asteraceae against rootknot nematode. Plant Pathology, 52, 395 - 407

RENČO, M., ČEREVKOVÁ, A. (2008): Occurrence and geographical distribution of cyst nematodes in cereals and grassland in the Slovak Republic. Helminthologia, 45, 143 $-146$

RenČO, M., D’ADdabBo, T., SAsanelli,, N., PAPAJOVÁ, I. (2007): The effect of five compost of different origin on the survival and reproduction of Globodera rostochiensis. Nematology 9, $537-543$

Ribeiro, R. C., Mizobutsi, E. H., Silva, D. G., Pereira, 
J. C. R., Zambolim, L. (1998): Control of Meloidogyne javanica on lettuce with organic amendments. Fitopatologia Brasileira 23, $42-44$

RODRÍGUEZ-KÁBANA, R. (1986): Organic and inorganic nitrogen amendments to soil as nematode suppressants. $J$. Nematol. 18, 129 - 135

Rodríguez-Kábana, R., Eustaun, V., Pinochet, J., MARFÁ, O. (1995): Mixtures of olive pomace with different nitrogen sources for the control of Meloidogyne spp. on tomato. J. Nematol. 27(4S), 575 - 584

SASANELli, N. (1994): Tables of Nematode-Pathogenicity. Nematologia mediterranea, 22: 153 - 157

SASANELli, N., D'ADDABBO T. (2002): Effetto dello spandimento nel terreno di reflui dell'industria olearia sui nematodi fitoparassiti (English: Effect of composted olive mill wastes on phytoparasitic nematodes). Agricoltura $e$ Ricerca, 187: 121 - 126

Sasanelli, N., D’AdDabBo, T., Convertini, G. Ferri, D. (2002): Soil Phytoparasitic Nematodes Suppression and Changes of Chemical Properties Determined by Waste Residues from Olive Oil Extraction. In Proceedings of $12^{\text {th }}$ ISCO Conference, May 26-31, 2002 Beijing China. Vol. III: $588-592$
Sasanelli, N., Ciccarese, F., PAPAJOVÁ, I. (2008): Aphanocladium album by via sub-irrigation in the control of Pyrenochaeta lycopersici and Meloidogyne incognita on tomato in a plastic-house. Helminthologia, 45: $137-142$ SEINHORST, J. W. (1986): Effect of nematode attack on the growth and yield of crop plants. In: LAMBERTI, F., TAYlor, C. E. (Eds) Cyst Nematodes. Plenum Press, New York, London, pp.191 - 209

STIRLING, G. R. (1991): Mode of action of organics amendments against nematode. In: Biological Control of Plant Parasitic Nematodes. Progress, Problems and Prospects. C.A.B. International, pp. $170-185$

SzCZECH, M., RondOMANski, W., BRZESKI, M. W., Smolinska, U., Kotowski, J. F. (2003): Suppressive effect of a commercial earthworm compost on some root infecting pathogens of cabbage and tomato. Biol. Agric. Hortic. 10, $47-52$

YaO, S., Merwin, I. A., AbAwi, G. S., Thies, J. E. (2006): Soil fumigation and compost amendment alter soil microbial community composition but do not improve tree growth or yield in an apple replant site. Soil Biol. Biochem. $38,587-599$ 